\title{
Salvia ceratophylla L. from South of Jordan: new insights on chemical composition and biological activities
}

\author{
Mohammad Sanad Abu-Darwish ${ }^{1,2} \cdot$ Célia Cabral $^{3,4,5} \cdot{\text { Zulfigar } \text { Ali }^{2} \cdot \text { Mei Wang }^{2} \cdot \text { Shabana I. Khan }}^{2}$. \\ Melissa R. Jacob ${ }^{2}$. Surendra K. Jain ${ }^{2}$ - Babu L. Tekwani' ${ }^{2}$ Fazila Zulfiqar ${ }^{2} \cdot$ Ikhlas A. Khan ${ }^{2} \cdot$ Hatem Taifour $^{6}$. \\ Lígia Salgueiro $^{7} \cdot$ Thomas Efferth $^{8}$
}

Received: 29 July 2020 / Accepted: 1 August 2020 / Published online: 27 August 2020

(c) The Author(s) 2020

\begin{abstract}
In Jordan, Salvia ceratophylla L. is traditionally used in the treatment of cancer, microbial infections, and urinary disorders. This study aimed: (1) to chemically characterize S. ceratophylla essential oil (EO) from South Jordan, by gas chromatography (GC) and gas chromatography-mass spectrometry (GC-MS); and (2) to evaluate in vitro the cytotoxic, anti-inflammatory, and antiprotozoal activities of the EO, it's predominant components, and the hexane (A), ethyl acetate (B), methanol (C) and crude-methanol extracts (D). The analysis revealed that the EO has 71 compounds, with linalool (54.8\%) as main constituent. Only the hexane extract (A) showed some cytotoxic activity against SK-MEL, KB, BT-549, SK-OV-3, LLC-PK1 and VERO cells lines with $\mathrm{IC}_{50}$ between 60 and $>100 \mu \mathrm{g} / \mathrm{mL}$. The EO inhibited NO production $\left(\mathrm{IC}_{50} 90 \mu \mathrm{g} / \mathrm{mL}\right)$ and NF- $\mathrm{kB}$ activity $\left(\mathrm{IC}_{50} 38 \mu \mathrm{g} / \mathrm{mL}\right.$ ). The extracts $\mathrm{A}, \mathrm{B}$, and D inhibited NO production and NF- $\mathrm{\kappa B}$ activity with $\mathrm{IC}_{50}$ between 32 and $150 \mu \mathrm{g} / \mathrm{mL}$. Linalool considerably inhibited NO production $\left(\mathrm{IC}_{50} 18 \mu \mathrm{g} / \mathrm{mL}\right)$. The extracts tested did not exhibit antileishmanial activity. Regarding antitrypanosomal activity, the EO exhibited significant results with $\mathrm{IC}_{50} 2.65 \mu \mathrm{g} / \mathrm{mL}$. In conclusion, Jordan S. ceratophylla EO represents a rich source of linalool and bears a promising therapeutic potential for further antitrypanosomal drug development.
\end{abstract}

Keywords Lamiaceae $\cdot$ Essential oil $\cdot$ Chemical composition $\cdot$ Cytotoxicity $\cdot$ Anti-inflammatory activity $\cdot$ Neglected diseases

\section{Introduction}

Salvia ceratophylla L. (Arabic: Lusan Al-haea, English: horn-leaved sage) is a biennial lemon-scented herb and one of the 19 indigenous Salvia species native in Jordan [1]. This species grows in diverse Jordanian geographic areas,

Célia Cabral

celia.cabral@fmed.uc.pt

1 Department of Basic and Applied Sciences, Al-Balqa Applied University, Al-Salt 19117, Jordan

2 National Center for Natural Products Research, School of Pharmacy, University of Mississippi, University, MS 38677, USA

3 Coimbra Institute for Clinical and Biomedical Research (iCBR), Faculty of Medicine, University of Coimbra, 3000-548 Coimbra, Portugal

4 Center for Innovative Biomedicine and Biotechnology (CIBB), University of Coimbra, 3000-548 Coimbra, Portugal such as Mafraq, Ajlun, Ma'an, Tafila and Dana [1] and Wadi Musa [2]. It is also found in several Asian-temperate regions, including Caucasus, Transcaucasus, Middle Asia (Turkmenistan), and Near East (Afghanistan, Iran, Iraq, Lebanon, Syria, Palestine, Israel, and Turkey) [3, 4].

5 Centre for Functional Ecology, Department of Life Sciences, University of Coimbra, Calçada Martim de Freitas, 3000-456 Coimbra, Portugal

6 School of Geosciences, University of Edinburgh, 219 Crew Building, King's Buildings, Edinburgh EH9 3FF, UK

7 CIEPQPF/Faculty of Pharmacy, University of Coimbra, Health Sciences Campus, Azinhaga de S. Comba, 3000-548 Coimbra, Portugal

8 Department of Pharmaceutical Biology, Institute of Pharmaceutical and Biocmedical Sciences, Johannes Gutenberg University, Staudinger Weg 5, 55128 Mainz, Germany 
S. ceratophylla is used in traditional medicine of the Middle East against various ailments, e.g. inflammation, fungal, and nociceptive diseases [4-6]. In Middle Eastern countries such as Jordan, Lebanon, and Syria, the herbalists prescribe Salvia species as boiled tea to relieve abdominal pain, headaches, stomachaches, and to treat cancer, microbial infections, asthma, coughs and other pulmonary and urinary disorders [7]. It is also recommended in folk medicine to disinfect homes after sickness [8]. Several Salvia species and their essential oils are used in various traditional medicines to treat malaria [9, 10] and leishmaniasis [11].

Despite the composition of S. ceratophylla essential oil (EO) grown in various habitats of the Near East countries has been analyzed and a wide variation in their composition has been reported [3, 12-14], there is only one report on the composition of $S$. ceratophylla EO originated from the middle of Jordan [15].

Few reports showed the biological activities of $S$. ceratophylla extracts from various locations in the Middle East. Some $S$. ceratophylla extracts revealed cytotoxic activity against some types of cancer cell lines $[16,17]$.

The antioxidant activity of $S$. ceratophylla originated from Turkey and Iran has been assessed by different methods. Gürsoy et al. [3] showed the antioxidant activity of essential oil of S. palaestina and S. ceratophylla from Turkey. The $S$. ceratophylla chloroform extract inhibited the activity of butyrylcholine esterase [18]. Among 9 Salvia species from Iran, the methanolic extract of S. glutinosa and $S$. ceratophylla revealed the strongest antioxidant activity [17]. The anti-inflammatory activity of the EO from Salvia species is mediated by the inhibition of nitric oxide (NO) production and nuclear kappa $\mathrm{B}(\mathrm{NF}-\kappa \mathrm{B})$ activation [10]. Linalool and linalyl acetate, the major volatile constituents of the EO of several aromatic plants exhibit in vivo strong anti-inflammatory activity against Carrageenin-induced edema [19].

The extracts and EO of some other Salvia species showed antiprotozoal activity against malaria, leishmaniasis and human African trypanosomiasis [20-22]. The hydroalcoholic extract of $S$. officinalis from Algeria completely inhibited the growth of Leishmania major [23]. Furthermore, linalool exhibited antileishmanial activity in a concentration-dependent fashion [24, 25]. Caryophyllene showed anti-protozoal activity against Leishmania donovani [26] and Trypanosoma brucei [27].

Only a few studies reported the biological activities of $S$. ceratophylla from Jordan. However, the anti-inflammatory activity of hexane, ethyl acetate and methanol extracts obtained from the aerial parts of Jordanian Salvia species have been evaluated by inhibition of croton oil-induced mouse ear edema [6]. Kasabri et al. [5] studied the inhibitory activity of the aqueous extracts of $S$. ceratophylla and other
Salvia species grown in Jordan against pancreatic triacylglycerol lipase, $\alpha$-amylase and $\alpha$-glucosidase. $S$. ceratophylla exhibited cytotoxic efficacy against $\mathrm{CaCo} 2$ cells with an $\mathrm{IC}_{50}$ value of $9.2 \pm 0.5 \mu \mathrm{g} / \mathrm{mL}$.

However, there is limited information about the chemical composition and biological activities of medicinal plants from Jordan flora. No studies have been carried out yet on $S$. ceratophylla EO from Dana Biosphere Reserve in southern Jordan and to the best of our knowledge, there are no previous reports on the antiprotozoal activity of this plant. Thus, the aim of this work was to evaluate for the first time the chemical composition of $S$. ceratophylla EO grown in Dana Biosphere Reserve (Southern Jordan), as well as, to assess the cytotoxic, antileishmanial, and antimalarial activities of its essential oil and other extracts.

\section{Materials and Methods}

\subsection{Plant Material}

Aerial parts of $S$. ceratophylla were collect during the spring season, throughout Dana Biosphere Reserve (South of Jordan). The voucher specimens were identified by Mr. Hatem Taifour (Researcher at School of GeoSciences, University of Edinburgh Edinburgh EH9 3FF, U.K.) and were deposited in the Herbarium of Shoubak University College, Al-Balqa Applied University, Jordan under the number \#0009- ScDSh-2015 and in the Herbarium of National Center for Natural Products Research, School of Pharmacy, University of Mississippi, USA under the number \#18,330. The plant material for extraction was air dried and crushed into small pieces with a hammer mill before extraction.

\subsection{Isolation of Extracts}

\subsubsection{Isolation of Essential Oil}

To isolate EO, the crushed aerial parts of S. ceratophylla were hydro distillated during $3 \mathrm{~h}$ with a Clevenger-type apparatus, according to the European Pharmacopoeia [28]. The oil obtained was dried over anhydrous sodium sulphate and kept at $4{ }^{\circ} \mathrm{C}$ until analyzed and tested.

\subsubsection{Extraction of Non-polar and Polar Extracts}

The hexane, ethyl acetate, and methanol extracts from the crude areal parts of $S$. ceratophylla were obtain as follows: powdered plant material (600 g) was soaked with hexane followed by ethyl acetate, and then methanol for $48 \mathrm{~h}$ for each solvent in ratio of $500 \mathrm{~mL}$ per $100 \mathrm{~g}$. The process of extraction for each solvent was repeat several times to ensure 
complete extraction of the compounds. The obtained extracts for each solvent were combine together and subject to rotary evaporation at $40{ }^{\circ} \mathrm{C}$. The evaporation led to dry hexane (A), ethyl acetate (B), and methanol (C) extracts with yields of $4.21 \%, 1.77 \%$ and $6.93 \%$, respectively.

\subsubsection{Extraction of Crude Methanol Extract}

A sample of $50 \mathrm{~g}$ of powder plant materials was soaked in $250 \mathrm{~mL}$ of methanol for $48 \mathrm{~h}$. The process of extraction was repeat several times to ensure complete extraction of the compounds. The obtained methanol extracts were filter combined and subject to rotary evaporation at $40{ }^{\circ} \mathrm{C}$. The obtained crude methanol dry extract (D) yielded $18.96 \%$. All extracts (A-D) were freeze-dry and stored at $4{ }^{\circ} \mathrm{C}$ for further analyses.

\subsection{Chemical Composition}

\subsubsection{Chemicals}

GC-grade n-hexane (>99\%) and the reference standards were purchased from Sigma-Aldrich or isolated in the National Center for Natural Products Research, University of Mississippi. A mixture of n-alkanes $\left(\mathrm{C}_{8} \mathrm{H}_{18}-\mathrm{C}_{23} \mathrm{H}_{48}\right)$ was use in the determination of retention indices and were purchased from PolyScience Corp.

\subsubsection{Gas Chromatography-Mass Spectrometry (GC-MS)}

Gas chromatography analysis was performed in an Agilent 7890B GC equipped with a 5975C quadruple mass spectrometer and a 7693-auto sampler. Separation was achieve using an Agilent J\&W HP-1 (100\% dimethyl-polysiloxane) fused silica capillary column $(60 \mathrm{~m} \times 0.25 \mathrm{~mm}$ I.D. $\times 0.25 \mu \mathrm{M}$ film thickness). Helium was the carrier gas at a constant flow rate of $1.5 \mathrm{~mL} / \mathrm{min}$. Oven temperature program: $50{ }^{\circ} \mathrm{C}$ hold for $2 \mathrm{~min}$, after $50-170{ }^{\circ} \mathrm{C}$ at $2{ }^{\circ} \mathrm{C} /$ min, $170-250{ }^{\circ} \mathrm{C}$ at $6{ }^{\circ} \mathrm{C} / \mathrm{min}$ (hold $10 \mathrm{~min}$ ). The injector temperature was $250{ }^{\circ} \mathrm{C}$, the injection volume was $0.5 \mu \mathrm{L}$ and a split ratio of 50:1. The EO was diluted in n-hexane $(0.5 \% \mathrm{v} / \mathrm{v})$ prior to $\mathrm{GC} / \mathrm{MS}$ analysis.

Mass spectra were record at $70 \mathrm{eV}$ at a scan mode from $\mathrm{m} / \mathrm{z} 40$ to 500 . The transfer line and the ion source temperatures were $260{ }^{\circ} \mathrm{C}$ and $230^{\circ} \mathrm{C}$, respectively. Data acquisition was made with Agilent MSD Chemstation (F.01.03.2357).

\subsubsection{Identification of Individual Components}

Compound identification was carried out through comparison of the spectra with the database (Wiley and NIST) using a probability-based matching algorithm. Further identification was based on the relative retention indices compared with reference standards and literature data [29].

\subsection{Cytotoxic activity}

All cell lines used in this study were purchase from American Type Culture Collection (ATCC, Rockville, MD). The cytotoxic activity of the EO, extracts isolated from $S$. ceratophylla and pure compounds was determined in vitro against various human cancer cells: skin malignant melanoma (SK-MEL), human KB carcinoma (KB), breast ductal carcinoma (BT-549), ovarian carcinoma (SK-OV-3), and in two non-cancerous mammalian kidney cell lines (LLC-PK1 and VERO).

Cells were seed at a density of 25,000 cells/well and incubated during $24 \mathrm{~h}$. The tested EO, extracts and pure compounds were added separately at studied concentrations and cells were re-incubated during $48 \mathrm{~h}$. After incubation time, the viability of cells was assessed by using Neutral Red Dye as described [30]. DMSO was use as negative control and doxorubicin as positive control.

\subsection{Anti-inflammatory Activity}

\subsubsection{Inhibition of Cellular Oxidative Stress Assay}

The cellular antioxidant activity of $S$. ceratophylla $\mathrm{EO}$ and other extracts was measured in human HepG2 hepatoma cells This assay determines the ability of test samples to prevent intracellular generation of peroxyl radicals in response to 2,2-azobis (2-amidinopropane) dihydrochloride (ABAP, Sigma-Aldrich, St Louis, MO, USA).

HepG2 cells were culture in Dulbecco's Modified Eagle Medium (DMEM) supplemented with 10\% fetal bovine serum (FBS), 50 units $/ \mathrm{mL}$ penicillin and $50 \mu \mathrm{g} / \mathrm{mL}$ streptomycin. Cells were seed in $96-$ well plates $(60,000$ cells/well) and incubated for $24 \mathrm{~h}$. The tested samples were diluted in serum free medium containing $25 \mu \mathrm{M} 2^{\prime}, 7^{\prime}$, dichoroflouresceine diacetate (DCFH-DA, Invitrogen, Carlsbad, CA, USA). The cells were wash with PBS and treated with test samples during $1 \mathrm{~h}$. The medium containing tested samples was removed, ABAP $(600 \mu \mathrm{M})$ was added and the plate was immediately placed on a Spectra Max plate reader for kinetic reading every 5 min during $1 \mathrm{~h}\left(37^{\circ} \mathrm{C}\right.$, emission at $538 \mathrm{~nm}$ and excitation at $485 \mathrm{~nm}$ ). Quercetin (Sigma-Aldrich) was use as positive control. To calculate the percentage of decrease in oxidative stress, the Area Under the Curve (AUC) of fluorescence versus time was used.

Decrease in oxidative stress (\%)

$$
=\text { AUC control }{ }^{100-} \text { [AUC tested samplex100] }
$$




\subsubsection{Nitric Oxide (NO) Measurement}

The NO inhibition by EO, extracts of S. ceratophylla and pure compounds, was assess by the following methodology [31]. Briefly, mouse macrophage cells (RAW 264.7) were culture in phenol red free RPMI medium with $10 \%$ bovine calf serum and $100 \mathrm{U} / \mathrm{mL}$ penicillin and $100 \mu \mathrm{g} / \mathrm{mL}$ streptomycin.

Cells were seed in 96-well plates (50,000 cells/well) and incubated during $24 \mathrm{~h}$. The tested samples were dilute in serum free medium, incubated during $30 \mathrm{~min}$, then lipopolysaccharide (LPS, $5 \mu \mathrm{g} / \mathrm{mL}$ ) was added and cells were incubated for further $24 \mathrm{~h}$. The level of nitrite in the cell supernatant was measure by using Griess reagent. The inhibition of nitrite production by the tested samples was calculate in comparison to the vehicle control. Parthenolide (SigmaAldrich) was use as positive control. $\mathrm{IC}_{50}$ values were obtain from dose curves.

\subsubsection{Assay for Inhibition of NF-KB Activity}

The inhibition activity of tested samples against NF- $\kappa \mathrm{B}$ was evaluate as described [31]. The SW 1353 human chondrosarcoma cell line was culture in a mixture of Dulbecco's Modified Eagle's Medium (DMEM) and Ham's F-12 Nutrient (DMEM/F12) supplemented with 10\% FBS, 100 U/Ml penicillin and $100 \mu \mathrm{g} / \mathrm{mL}$ streptomycin. Cultured cells were washed in antibiotic and FBS-free DMEM/F12 medium and then re-suspended in FBS-free DMEM/F12 medium containing $2.5 \%$ FBS. NF-кB luciferase plasmid construct was added to the cell suspension in a concentration of $50 \mu \mathrm{g} /$ $\mathrm{mL}$ and incubated for $5 \mathrm{~min}$ at $25^{\circ} \mathrm{C}$. The cells were transfected by electroporation at $160 \mathrm{~V}$ and one $70 \mathrm{~ms}$ pulse using BTX disposable cuvettes (model 640 in a BTX Electro Square Porator T 820_BTX I, San Diego, CA, USA), Transfected cells were plate in 96-well plates at a density of $1.25 \times 10^{5}$ cells per well in $200 \mu \mathrm{L}$ of DMEM/F12 containing $10 \%$ FBS and antibiotics. After incubation for $24 \mathrm{~h}$, the cells were treated with test samples for $30 \mathrm{~min}$ and then induced with PMA ( $70 \mathrm{ng} / \mathrm{mL})$ for $8 \mathrm{~h}$. The inhibition of $\mathrm{NF}-\kappa \mathrm{B}$ activity by EO, other extracts, and pure compounds was calculated in comparison to vehicle control. The $\mathrm{IC}_{50}$ values were obtain from the dose curves. Parthenolide was use as positive control.

\subsection{Antileishmanial and Antitrypanosomal Activities}

\subsubsection{Sample Preparation}

EO and extracts (A-D) at a stock concentration of $20 \mathrm{mg} / \mathrm{mL}$ were dilute to $4 \mathrm{mg} / \mathrm{mL}$ with DMSO. The obtained solutions ( $4 \mathrm{mg} / \mathrm{mL}$ ) were four-fold diluted with incomplete RPMI medium to $1 \mathrm{mg} / \mathrm{mL}$. Pure compounds at a stock concentration of $2 \mathrm{mg} / \mathrm{mL}$ in DMSO were diluted four-fold with incomplete RPMI medium to $0.5 \mathrm{mg} / \mathrm{mL}$.

\subsubsection{In Vitro Antileishmanial and Antitrypanosomal Assays}

The extracts and pure compounds (highest concentrations $20 \mu \mathrm{g} / \mathrm{mL}$ for extracts and $10 \mu \mathrm{g} / \mathrm{mL}$ for pure compounds) were subject to different tests, namely Leishmania donovani promastigote assay, L. donovani axenic amastigote assay, L. donovani THP1 macrophage amastigote assay, Trypanosoma brucei trypamastigotes assay and THP1 toxicity assay. Alamar Blue assay was perform as previously described by other authors [32, 33].

These assays have been adapted to 384-well micro-plate format. A 3-4 days old culture of Leishmania donovani promastigotes harvested in the exponential growth phase was diluted with RPMI medium to $1 \times 10^{6}$ cells $/ \mathrm{mL}$ for promastigote assays. A 3-4 days old culture of Leishmania donovani axenic amastigotes was diluted with RPMI medium to $2 \times 10^{6}$ cells $/ \mathrm{mL}$ for axenic amastigote assays. A 2 days old culture of Trypanosoma brucei harvested in the exponential phase was diluted with Iscove's Modified Dulbecco's Medium (IMDM) to $5 \times 10^{3}$ cells $/ \mathrm{mL}$ for the antitrypanosomal assay.

Samples were added to the $L$. donovani promastigotes, $L$. donovani axenic amastigotes or $T$. brucei trypamastigotes cultures. The extracts were initially test at single concentrations of $20 \mathrm{mg} / \mathrm{mL}$ for primary screening. The active extracts and pure compounds were test at three or six concentrations ranging from 10 to $0.0032 \mu \mathrm{g} / \mathrm{mL}$. The plates were incubated at $26^{\circ} \mathrm{C}$ for $72 \mathrm{~h}\left(37^{\circ} \mathrm{C}\right.$ for axenic amastigotes and T. brucei trypamastigotes) and growth of cultured parasites was determined by the Alamar Blue assay [32 33].

The extracts and single compounds were also test against L. donovani intracellular amastigotes in THP1 cells employing a recently developed parasite-rescue and transformation assay [15].

\subsection{THP1 Toxicity Assay and Macrophage Amastigote Assay}

A 4 days old THP1 cell culture harvested in the exponential growth phase was diluted with RPMI medium to $2.5 \times 10^{5}$ cells/mL. PMA was added to a final concentration of $25 \mathrm{ng} /$ mL. A PMA treated culture was dispense in experimental culture plates and incubated overnight at $37{ }^{\circ} \mathrm{C}$ in a $5 \% \mathrm{CO}_{2}$ incubator. The plates with differentiated THP1 cells were wash with serum-free medium. For THP1 toxicity assay, the diluted test samples (extracts or pure compounds) were add over differentiated THP1 cells and plates were incubated during $48 \mathrm{~h}$ at $37{ }^{\circ} \mathrm{C}$ in a $5 \% \mathrm{CO}_{2}$ incubator. Cell 
growth was determined by the Alamar Blue assay. $\mathrm{IC}_{50}$ and $\mathrm{IC}_{90}$ values were calculate from dose response curves using XLFit® [32].

\section{Results and Discussion}

\subsection{Essential Oil Composition}

In this study, the yield $(0.34 \pm 0.001 \%)$ of S. ceratophylla $\mathrm{EO}$ was higher than in other studies performed in the middle of Jordan, where the yield was $0.1 \%$ [15]. It is also lower than those grown in Turkey with a yield of $0.4 \%$ [13] and $0.8 \%$ [3] and in Iran $(0.6 \%,[12])$. Usually, the yield variation of $S$. ceratophylla $\mathrm{EO}$ is relate to the influence of environmental factors linked to predominant climatic and geographical differences in various growth areas $[34,35]$.

The EO was analyzed by GC and GC/MS, the identified components and their relative percentages are listed in Table 1. Seventy-one components were identified, representing $93.5 \%$ of the total constituents (Table 1). The major compounds of the EO were linalool (54.8\%), germacrene-D (6.4\%), bicyclogermacrene (5\%) and the bicyclic diterpene alcoholsclareol (4.3\%). As far as we know, there is no previous report on the $S$. ceratophylla EO composition originated from Dana Biosphere Reserve (Southern Jordan). However, there are some works reporting the chemical composition of S. ceratophylla originated from middle of Jordan [15], Turkey [3, 13, 14] and Iran [12].

The EO of the dried flowers of S. ceratophylla grown in the middle of Jordan was dominate by oxygenated monoterpenes (58.28\%) (Al Jaber, 2016). S. ceratophylla oil grown in Elazığ, Turkey is characterized by a high amount of germacrene D (27.4\%) [13].

Gürsoy et al. [3] also reported that the composition of S. ceratophylla EO grown in Turkey, was dominated by $\gamma$-muurolene (11.4\%) and $\alpha$-pinene (7.6\%) as major compounds. Furthermore, the oils of $S$. ceratophylla grown in Kayseri, Elazı $\breve{g}$ and Adıyaman, Turkey were analyzed: $\alpha$-Pinene (27.0\%), $\beta$-pinene (16.3\%) and $\beta$-caryophyllene $(10.6 \%)$ were the major components in the Kayseri sample, $\alpha$-pinene $(24.6 \%)$ and $\beta$-pinene $(10.3 \%)$ in the Elazı $\breve{g}$ samples, $\alpha$-pinene $(23.7 \%), 1,8$-cineole $(8.9 \%)$ and borneol (7.0\%) in the Adiyaman sample. The S. ceratophylla EO from Iran was dominated by cis-thujopsene (10.9\%), cyclopentadecanolide $(6.1 \%)$, methyl linoleate $(4.5 \%)$ and $\alpha$-humulene (3.6\%) [12].

Our results revealed that $S$. ceratophylla EO, originated from southern Jordan showed significant differences compared with the oils obtained from samples grown in other locations and was distinguished by its high concentration of linalool. Our results also showed that this EO is distinct by containing the bicyclic diterpene alcohol sclareol, while
Table 1 Composition of Salvia ceratophylla L. essential oil from Dana Biosphere Reserve, South Jordan

\begin{tabular}{|c|c|c|c|}
\hline No. & RRI & Compounds & $\%$ \\
\hline & 969 & $\beta$-Pinene & 0.1 \\
\hline & 981 & $\beta$-Myrcene & 0.1 \\
\hline & 1010 & 1,8-Cineole & 2.0 \\
\hline & 1019 & trans-Ocimene & 0.1 \\
\hline & 1029 & cis-Ocimene & 0.4 \\
\hline & 1038 & $\gamma$-Terpinene & 0.1 \\
\hline & 1045 & trans-Linalool oxide & 0.2 \\
\hline & 1058 & cis-Linalool oxide & 0.2 \\
\hline & 1074 & Linalool & 54.8 \\
\hline & 1128 & $\delta$-Terpineol & 0.1 \\
\hline & 1142 & Terpinen-4-ol & 0.1 \\
\hline & 1152 & $\alpha$-Terpineol & 1.2 \\
\hline & 1192 & cis-Geraniol & 0.1 \\
\hline & 1217 & Geraniol & 0.5 \\
\hline & 1224 & Linalyl acetate & 0.2 \\
\hline & 1319 & $\delta$-Elemene & 0.4 \\
\hline & 1331 & Neryl acetate & 0.2 \\
\hline & 1333 & $\alpha$-Cubebene & 0.1 \\
\hline & 1350 & Geranyl acetate & 0.2 \\
\hline & 1361 & $\alpha$-Copaene & 1.2 \\
\hline & 1369 & $\beta$-Bourbonene & 0.2 \\
\hline & 1375 & $\beta$-Elemene & 1.2 \\
\hline & 1397 & $\alpha$-Gurjunene & 0.2 \\
\hline & 1403 & Aristolene & 1.0 \\
\hline & 1404 & $\beta$-Caryophyllene & 1.9 \\
\hline & 1415 & $\beta$-Copaene & 0.1 \\
\hline & 1425 & $\alpha$-Bergamotene & 0.5 \\
\hline & 1426 & Aromandendrene & 0.1 \\
\hline & 1438 & Isoledene & 0.1 \\
\hline & 1440 & Humulene & 0.1 \\
\hline & 1448 & Alloaromadendrene & 0.1 \\
\hline & 1462 & $\gamma$-Gurjunene & 0.1 \\
\hline & 1465 & $\gamma$-Muurolene & 0.2 \\
\hline & 1467 & Guaia-1(10),11-diene & 0.2 \\
\hline & 1470 & Germacrene D & 6.4 \\
\hline & 1475 & $\beta$-Selinene & 0.1 \\
\hline & 1480 & $\delta$-Selinene & 0.4 \\
\hline & 1483 & Cubebol & 0.1 \\
\hline & 1487 & Bicyclogermacrene & 5.0 \\
\hline & 1491 & $\alpha$-Muurolene & 0.1 \\
\hline & 1493 & $\delta$-Cadinene & 0.1 \\
\hline & 1505 & $\gamma$-Cadinene & 0.2 \\
\hline & 1511 & cis- $\alpha$-Santalol & 0.1 \\
\hline & 1551 & $\beta$-Maaliene & 0.1 \\
\hline & 1560 & Maaliol & 0.1 \\
\hline & 1565 & Palustrol & 0.2 \\
\hline & 1568 & Spathulenol & 2.4 \\
\hline & 1575 & Caryophyllene oxide & 0.5 \\
\hline & 1580 & Globulol & 0.5 \\
\hline
\end{tabular}


Table 1 (continued)

\begin{tabular}{|c|c|c|c|}
\hline No. & RRI & Compounds & $\%$ \\
\hline & 1585 & Salvial-4(14)-en-1-one & 0.1 \\
\hline & 1589 & Viridiflorol & 0.3 \\
\hline & 1592 & Cubeban-11-ol & 0.1 \\
\hline & 1600 & $\beta$-Eudesmol & 0.1 \\
\hline & 1603 & Ledol & 0.1 \\
\hline & 1612 & Neointermedeol & 0.1 \\
\hline & 1622 & Junenol & 0.1 \\
\hline & 1628 & Isospathulenol & 0.3 \\
\hline & 1633 & Di-epi-1,10-cubenol & 0.1 \\
\hline & 1646 & $T$-Muurolol & 0.6 \\
\hline & 1650 & $\delta$-Cadinol & 0.1 \\
\hline & 1652 & Cubenol & 0.1 \\
\hline & 1658 & Aromadendrene oxide & 0.3 \\
\hline & 1661 & $\alpha$-Cadinol & 1.0 \\
\hline & 1679 & Isoaromadendrene epoxide & 0.1 \\
\hline & 1688 & Ledene oxide & 0.1 \\
\hline & 1707 & Shyobunol & 0.4 \\
\hline & 1727 & 8-Hydroxylinalool & 0.1 \\
\hline & 1984 & Manoyl oxide & 0.7 \\
\hline & 2031 & Epimanool & 0.5 \\
\hline & 2133 & trans-Geranylgeraniol & 0.1 \\
\hline & 2166 & Sclareol & 4.3 \\
\hline & & Total & 93.5 \\
\hline
\end{tabular}

Compounds listed in order to their elution on the HP-1 column RRI Relative retention indices calculated against $\mathrm{C}_{8}-\mathrm{C}_{23} n$-alkanes on the apolar HP-1 column

$\%$ calculated from GC/MS data

this compound was absent in $S$. ceratophylla from Middle Jordan [35], Turkey [3, 13, 14] and Iran [12]. This variation might be ascribed to the influence of various factors such as seasonal variation and some environmental conditions such as climate, heavy metals pollution and type of soil, in which the plants were grown $[35,36]$. Furthermore, harvesting time, temperature and drying period of plants, may also influence the yield of the EO and their phytochemical composition, because these factors are known to increase the concentration of some aromatic oil components, especially linalool [37]. Kumar et al. [38] reported higher contents of linalool in S. sclarea under high daily light exposure, while the highest content of germacrene D and sclareol required $50 \%$ and $75 \%$ of shade, respectively.

Moreover, the EO of other Salvia species grown in Jordan were dominate by linalool as major component. Linalool was the major component in the oils of fresh and dry aerial parts of $S$. dominica (31.4\% and $18.3 \%$, respectively) [39]. The main compound of EO extracted from fresh $S$. verbenaca was mainly linalool [40].

\subsection{Cytotoxic Activity Against Cancer Cells}

The cytotoxic activity of $S$. ceratophylla EO and other extracts against cancer and non-cancer cell lines is summarize in Table 2. To the best of our knowledge, the cytotoxic activity of $S$. ceratophylla $\mathrm{EO}$ is reporting here for the first time. The EO (up to a concentration of $100 \mu \mathrm{g} / \mathrm{mL}$ ), linalool and other tested pure compounds (up to a concentration of $10 \mu \mathrm{g} / \mathrm{mL}$ ) did not exhibit cytotoxic activities against all cell lines tested. In agreement with our results, other reports showed that linalool did not exhibit cytotoxic activity up to a concentration of $200 \mu \mathrm{g} / \mathrm{mL}$ against several cancer cell lines [41]. Nevertheless, linalool had significant cytotoxic activity against various cancer cell lines, such as BCC-1/KMC, AGS, RTCC-1/KMC, U2OS, HeLa, H520, H661, OSCC-1/

Table 2 Cytotoxic activity $\left(\mathrm{IC}_{50}\right)$ of $S$. ceratophylla EO, polar and non-polar extracts and pure compounds

\begin{tabular}{|c|c|c|c|c|c|c|}
\hline \multirow[t]{4}{*}{ Sample code } & \multicolumn{4}{|l|}{ Cancer cell lines } & \multirow{2}{*}{$\begin{array}{l}\text { Kidney epithelial } \\
\text { LLC-PK1 }\end{array}$} & \multirow{2}{*}{$\begin{array}{l}\text { Kidney fibroblast } \\
\text { Vero }\end{array}$} \\
\hline & SK-MEL & $\mathrm{KB}$ & BT-549 & SK-OV-3 & & \\
\hline & $\mathrm{IC}_{50}$ & $\mathrm{IC}_{50}$ & $\mathrm{IC}_{50}$ & $\mathrm{IC}_{50}$ & $\mathrm{IC}_{50}$ & $\mathrm{IC}_{50}$ \\
\hline & $\mu \mathrm{g} / \mathrm{mL}$ & $\mu \mathrm{g} / \mathrm{mL}$ & $\mu \mathrm{g} / \mathrm{mL}$ & $\mu \mathrm{g} / \mathrm{mL}$ & $\mu \mathrm{g} / \mathrm{mL}$ & $\mu \mathrm{g} / \mathrm{mL}$ \\
\hline EO & NA & NA & NA & NA & NA & NA \\
\hline A & 95 & 70 & 70 & 100 & 60 & $>100$ \\
\hline B & $>100$ & NA & $>100$ & NA & NA & NA \\
\hline $\mathrm{C}$ & NA & NA & NA & NA & NA & NA \\
\hline $\mathrm{D}$ & NA & NA & NA & NA & NA & NA \\
\hline Linalool & NA & NA & NA & NA & NA & NA \\
\hline (-)trans-Caryophyllene & NA & NA & NA & NA & NA & NA \\
\hline$\alpha$-Terpineol & NA & NA & NA & NA & NA & NA \\
\hline Doxorubicin & 0.8 & 1.4 & 0.85 & 2 & 1.2 & $>5$ \\
\hline
\end{tabular}

$N A$ not active at $10 \mu \mathrm{g} / \mathrm{mL}$ for tested pure compound, and at $100 \mu \mathrm{g} / \mathrm{mL}$ for tested extracts 
KMC, J82 [42]. Furthermore, it enhanced the cytotoxic activity of doxorubicin against doxorubicin-resistant MCF-7 breast cancer cells [43].

In addition, among all $S$. ceratophylla polar and nonpolar extracts tested, the hexane extract (A) exhibited slight cytotoxic activity against all tested cancer cell lines. The $\mathrm{IC}_{50}$ values of A extract against SK-MEL, KB, BT-549, SK-OV-3, LLC-PK1 and VERO cells were 95, 70, 70, 100, 60 , and $>100 \mu \mathrm{g} / \mathrm{mL}$, respectively.

However, our results are in agreement with other previous reports. Abu-Dahab et al. [16] showed that 70\% ethanol extract of S. ceratophylla originated from Middle Jordan, exhibited low cytotoxic activity against several cancer cell lines. Furthermore, compared with other Salvia species from Jordan, the cytotoxic activity of S. ceratophylla $70 \%$ ethanol extract tested by using the sulforhodamine B colorimetric assay was comparable or even higher against the obesityrelated HCT116 and Caco2 colorectal carcinoma cell lines. The cytotoxic activity of $S$. ceratophylla against other obesity-related colorectal cell lines including HT29, SW620, and PDL was low, but higher than other Salvia species tested $[5,17]$ demonstrated that among various species of Salvia, $S$. ceratophylla methanol extract exhibited the strongest activity against human amelanotic melanoma (C32, CRL1585), and renal cell adenocarcinoma (ACHN, CRL1611) with $\mathrm{IC}_{50}$ values of 20.8 and $27.2 \mu \mathrm{g} / \mathrm{mL}$, respectively.

However, the variation in the cytotoxic activity of Salvia species may be due to the variation in their chemical composition, which can be influence by various factors such as chemotype and environment [4]. It was also reported that the cytotoxic activity of S.officinalis was affect by solvents used to obtain various extracts with various yields and quality of secondary metabolites [44].

\subsection{Inhibition of Oxidative Stress and Anti-Inflammatory Activity}

Nitric oxide (NO) is a free radical and its production at high levels was associated with inflammation and cancer. The metabolic pathway, which is known as the L-arginine: NO pathway is the main source for NO production in mammalian cells by a group of enzymes known as the nitric oxide synthases (NOS). Inducible NOS (iNOS; NOS2; or type II NOS) is the enzyme responsible for the involvement of NO in inflammatory processes. Accordingly, the inhibition of NO production has been considered as a potential anti-inflammatory and cancer chemo-preventive strategy [45]. On the other hand, the activation of NF- $\mathrm{KB}$ represents a mechanistic connection between chronic inflammation and tumorigenesis [46]. The Specificity Protein $1(\mathrm{Sp} 1)$ is a transcription factor, which binds GC/GT-rich promoter elements through three $\mathrm{C} 2 \mathrm{H} 2$-type zinc fingers that are present in their C-terminal domains [47]. Sp1 plays a major role in regulating the expression of genes involved in cell differentiation, cell cycle and apoptosis [48]. As compared with normal tissues, the activity and / or expression levels of Sp 1 were increased in some tumors such as carcinomas of breast [49], thyroid [50], and pancreas [51]. Sp1 plays an important regulatory role in controlling pathways of tumor development and progression. Thus, it may be an attractive therapeutic target for anticancer natural agents.

The EO of several Salvia species were being report to inhibit iNOS [52]. Therefore, we also evaluated, for the first time, the in vitro inhibiting intracellular oxidative stress activity of the EO and polar and nonpolar extracts $S$. ceratophylla from southern Jordan.

With exception of the EO, which did not decrease the oxidative stress, our results revealed that all other extracts exhibited antioxidant activity by inhibiting intracellular oxidative stress (Table 3). The hexane (A) and ethyl acetate (B) extracts were the most active in decreasing oxidative stress. At the concentration $1000 \mu \mathrm{g} / \mathrm{mL}$ the decrease by the extracts was 50 and $47 \%$, respectively, while at the concentration $500 \mu \mathrm{g} / \mathrm{mL}$ the decrease by the extracts was 56 and $25 \%$, respectively. Among all tested pure compounds, only caryophyllene showed weak activity in decreasing oxidative stress by 35 and $31 \%$ at concentrations of 500 and $250 \mu \mathrm{g} /$ $\mathrm{mL}$, respectively.

The EO showed the lowest inhibition in NO production with an $\mathrm{IC}_{50} 90 \mu \mathrm{g} / \mathrm{mL}$ and the highest inhibition activity against NF- $\mathrm{KB}$ with an $\mathrm{IC}_{50} 38 \mu \mathrm{g} / \mathrm{mL}$. At the same time, it did not inhibit the transcription factor $\mathrm{Sp}-1$. The extracts $\mathrm{A}, \mathrm{B}$ and $\mathrm{D}$ inhibited NO production and NF- $\mathrm{\kappa B}$ with $\mathrm{IC}_{50}$ values of 32,30 , and $40 \mu \mathrm{g} / \mathrm{mL}$, and 70,85 and $150 \mu \mathrm{g} / \mathrm{mL}$, respectively. The two non-polar extracts (hexane and ethyl acetate, A and B) of S. ceratophylla, inhibited Sp-1 with $\mathrm{IC}_{50}$ values of 70 and $160 \mu \mathrm{g} / \mathrm{mL}$, respectively.

Linalool was the only pure compound showing high and significant NO inhibition with an $\mathrm{IC}_{50}$ value of $18 \mu \mathrm{g} / \mathrm{mL}$. Linalool, caryophyllene and $\alpha$-terpineol inhibited NF- $\kappa \mathrm{B}$ activity with $\mathrm{IC}_{50}$ values of 60,45 and $100 \mu \mathrm{g} / \mathrm{mL}$, respectively. Caryophyllene was the only pure compound, which inhibited Sp-1 with an $\mathrm{IC}_{50}$ value of $48 \mu \mathrm{g} / \mathrm{mL}$.

The antioxidant activity of $S$. ceratophylla EO measured by different methods was moderate and slightly lower than the activity of $S$. palaestina essential oil [3]. Moreover, $S$. officinalis EO from Jordan showed anti-inflammatory effects and significantly inhibited NO production stimulated by LPS in macrophages, without affecting cell viability, in concentrations up to $0.64 \mu \mathrm{L} / \mathrm{mL}$ [53].

Nevertheless, the anti-inflammatory activity assessed by edema reduction was observed for $S$. ceratophylla ethylacetate extract with an $\mathrm{ID}_{50} 98 \mu \mathrm{g} / \mathrm{cm}^{2}$ compared with indomethacin, the hexane and methanol extract showed very low activity with an $\mathrm{ID}_{50}$ of $>300 \mu \mathrm{g} / \mathrm{cm}^{2}$ [6]. Moreover, using the FRAP method, S. ceratophylla exhibited significant 
Table 3 Anti-inflammatory activity of S. ceratophylla essential oil, other extracts and pure compounds

\begin{tabular}{|c|c|c|c|c|c|}
\hline Sample code & $\begin{array}{l}\% \text { decrease in } \\
1000 \mu \mathrm{g} / \mathrm{mL}\end{array}$ & $\begin{array}{l}\text { Oxidative stress } \\
500 \mu \mathrm{g} / \mathrm{mL}\end{array}$ & $\begin{array}{l}\text { NO inhibition } \\
\mathrm{IC}_{50}(\mu \mathrm{g} / \mathrm{mL})\end{array}$ & $\begin{array}{l}\text { NF- } \kappa \mathrm{B} \text { inhibition } \\
\mathrm{IC}_{50}(\mu \mathrm{g} / \mathrm{mL})\end{array}$ & $\begin{array}{l}\text { Sp-1 inhibition } \\
\mathrm{IC}_{50}(\mu \mathrm{g} / \mathrm{mL})\end{array}$ \\
\hline $\mathrm{EO}$ & NA & NA & 90 & 38 & NA \\
\hline A & 50 & 47 & 32 & 70 & 70 \\
\hline B & 56 & 25 & 30 & 85 & 160 \\
\hline $\mathrm{C}$ & 43 & 29 & NA & NA & NA \\
\hline \multirow[t]{2}{*}{$\mathrm{D}$} & 44 & 21 & 40 & 150 & NA \\
\hline & $500 \mu \mathrm{g} / \mathrm{mL}$ & $250 \mu \mathrm{g} / \mathrm{mL}$ & & & \\
\hline Linalool & NA & NA & 18 & 60 & NA \\
\hline Caryophyllene & 35 & 31 & NA & 45 & 48 \\
\hline$\alpha$-Terpineol & NA & NA & NA & 100 & NA \\
\hline Quercetin $25 \mu \mathrm{M}$ & 75 & - & - & - & - \\
\hline Parthenolide & - & - & 0.48 & 0.33 & - \\
\hline
\end{tabular}

NA Not active at tested concentration

antioxidant activity $290.7 \mu \mathrm{mol} \mathrm{FeSO}_{4} \mathrm{eq} / \mathrm{g}$ of dried extract [17].

However, the previously obtained results showed that linalool significantly inhibited carrageenin-induced hind paw edema $(55 \%, p=0.03)$ at a dose of $25 \mathrm{mg} / \mathrm{kg}$ [54]. Ma et al. [55] reported that the effect of linalool on cigarette smoke induced acute lung inflammation and showed that it suppressed the activation of NF- $\mathrm{KB}$ in a dose-dependent manner. Hassan et al. [46] showed that $\alpha$-terpineol inhibited the growth of cell lung carcinoma through significant inhibition of the NF- $\kappa B$ pathway.

However, in agreement with Gürsoy et al. [3] it is important to mention that the anti-oxidative activity of EOs or extracts were link with the polarity of their chemical constituents. EOs with non-polar secondary metabolites such as terpenoids, were minimally or not active. The anti-inflammatory and radical scavenging activity of $S$. ceratophylla may be ascribe to the high total phenolic contents, thus contributing to their electron transfer/hydrogen donating capability $[3,17,56]$.

\subsection{Antileishmanial and Antitrypanosomal Activities}

The present study provided for the first time, data on the activity of S. ceratophylla EO and other extracts (from Jordan) against $T$. brucei and $L$. donovani in promastigote and amastigote stages. Furthermore, this study demonstrated the antiprotozoal activity of pure compounds (linalool, $\alpha$-terpineol and $\beta$-caryophyllene).

Table 4 Antiprotozoal activity of S. ceratophylla essential oil, other extracts and pure compounds (only the antitrypanosomal activity)

\begin{tabular}{|c|c|c|c|c|c|c|c|c|c|c|c|}
\hline \multirow[t]{2}{*}{ Tested sample } & \multicolumn{2}{|c|}{$\begin{array}{l}\text { L. donovani } \\
\text { Promastigote }\end{array}$} & \multicolumn{2}{|c|}{$\begin{array}{l}\text { L. donovani } \\
\text { Amastigote }\end{array}$} & \multicolumn{2}{|c|}{$\begin{array}{l}\text { L. donovani } \\
\text { Amastig- } \\
\text { ote + THP1 }\end{array}$} & \multicolumn{2}{|c|}{ T. brucei } & \multicolumn{2}{|c|}{ THP1 cells toxicity } & \multirow[t]{2}{*}{$\begin{array}{l}\text { Tested } \\
\text { concentr-ations } \\
(\mu \mathrm{g} / \mathrm{mL})\end{array}$} \\
\hline & $\mathrm{IC}_{50}$ & $\mathrm{IC}_{90}$ & $\mathrm{IC}_{50}$ & $\mathrm{IC}_{50}$ & $\mathrm{IC}_{50}$ & $\mathrm{IC}_{90}$ & $\mathrm{IC}_{50}$ & $\mathrm{IC}_{90}$ & $\mathrm{IC}_{50}$ & $\mathrm{IC}_{90}$ & \\
\hline EO & NA & NA & NA & NA & NA & NA & 2.65 & \multicolumn{2}{|r|}{3.65} & NANA & $20-0.8$ \\
\hline A & NA & NA & NA & NA & NA & NA & NA & NA & NA & NA & $20-0.8$ \\
\hline $\mathrm{B}$ & NA & NA & NA & NA & NA & NA & 15.78 & 19.28 & NA & NA & $20-0.8$ \\
\hline $\mathrm{C}$ & NA & NA & NA & NA & NA & NA & NA & NA & NA & NA & $20-0.8$ \\
\hline $\mathrm{D}$ & NA & NA & NA & NA & NA & NA & NA & NA & NA & NA & $20-0.8$ \\
\hline Linalool & NA & NA & NA & NA & NA & NA & NA & NA & NA & NA & $10-0.4$ \\
\hline$\alpha$-terpineol & NA & NA & NA & NA & NA & NA & 6.04 & 8.22 & NA & NA & $10-0.4$ \\
\hline$\beta$-Caryophyllene & NA & NA & NA & NA & NA & NA & NA & NA & NA & NA & $10-0.4$ \\
\hline Amphotericin B & 0.140 & 0.324 & 0.181 & NA & NA & NA & NT & 0.426 & 0.375 & 0.190 & $2.0-0.08$ \\
\hline Pentamidine & 1.024 & 9.280 & 3.797 & NA & NA & NA & NT & - & - & 1.735 & $10-0.4$ \\
\hline$\alpha$-difluorome-thylornithine & NT & NT & NT & $\mathrm{T}$ & NT & NT & 4.792 & 7.760 & NT & NT & $20-0.8$ \\
\hline
\end{tabular}

$N A$ not active at tested concentration, $N T$ not tested against listed protozoans 
EO and extracts of $S$. ceratophylla and pure compounds did not exhibit antileishmanial activity against extracellular (promastigote) and intracellular (amastigote) forms of L. donovani at all tested concentrations (Table 4). On the other hand, the Jordan S. ceratophylla exhibited significant antitrypanosomal activity against $T$. brucei. The EO showed higher antitrypanosomal activity with $\mathrm{IC}_{50}$ and $\mathrm{IC}_{90}$ values of 2.65 and $3.61 \mu \mathrm{g} / \mathrm{mL}$, respectively. The inhibiting activity of the EO was better than that of the control ( $\alpha$-difluoromethylornithine) with $\mathrm{IC}_{50}$ and $\mathrm{IC}_{90}$ values of 4.792 and $7.76 \mu \mathrm{g} / \mathrm{mL}$. Among all extracts, the Ethyl acetate extract (B) was the only one that exhibited moderate antitrypanosomal activity against $T$. brucei with $\mathrm{IC}_{50}$ and $\mathrm{IC}_{90}$ values of 15.78 and $19.28 \mu \mathrm{g} / \mathrm{mL}$, respectively. Among the pure compounds, $\alpha$-terpineol was the only compound that exhibited antitrypanosomal activity against $T$. brucei similar to the control ( $\alpha$-difluoromethylornithine) with $\mathrm{IC}_{50}$ and $\mathrm{IC}_{90}$ values of 6.04 and $8.22 \mu \mathrm{g} / \mathrm{mL}$, respectively.

Interestingly, the results of human acute monocytic leukemia cells toxicity (THP1) showed that the S. ceratophylla EO, Ethyl acetate extract (B) and $\alpha$-terpineol did not exhibit cytotoxic effects on mammalian cells at the concentrations tested.

Other authors stated that extracts obtained from other Salvia species led to similar results than those of S. ceratophylla extracts, such as the activity of $S$. officinalis methanol extract from leaves against promastigote and amastigote forms of $L$. major [57]. Moreover, the liquid form of $S$. officinalis extract distributed in the German market did not show remarkable antileishmanial activity against $L$. donovani [21].

Morales et al. [25] studied the antileishmanial activity of various EO components such as linalool, carvacrol, geraniol and terpinen-4-ol against $L$. infantum promastigotes. Accordingly, among the compounds tested, carvacrol exhibited the highest activity at the lowest concentration of $6.25 \mu \mathrm{g} / \mathrm{mL}$ followed by linalool, which exhibited dosedependent antileishmanial activity. At a concentration of $37.5 \mu \mathrm{g} / \mathrm{mL}$ the inhibitory activity of linalool was similar to the control drug (Pentamidine). Moreover, linalool, the main EO component of Croton cajucara reduced the viability of L. amazonensis promastigotes at very low concentrations (MIC, $85.0 \mathrm{pg} / \mathrm{ml}$ ) and presented no cytotoxic effects against mammalian cells [24].

Ślusarczyk et al. [63] showed that among 880 plant and fungal extracts, the dichloromethane extract of $S$. miltiorrhiza was the only extract that inhibited $97 \%$ of $T$. brucei rhodesiense growth at the lowest concentration tested $(0.81 \mu \mathrm{g} / \mathrm{mL})$. Accordingly, the antitrypanosomal activity of S. miltiorrhiza dichloromethane extract was correlate with the presence of tanshinone-type diterpenoids, which also exhibited antitrypanosomal activity with $\mathrm{IC}_{50}$ values of $0.5 \mu \mathrm{M}$ to over $30 \mu \mathrm{M}$ against $T$. brucei rhodesiense [58].
Both, minor compound (nerolidol) and major compound (linalool) of Strychnos spinosa EO demonstrated high and selective activity towards Trypanosoma $(\mathrm{SI}=35.7$ and $>40$, respectively, and $\mathrm{IC}_{50}=1.7$ and $2.5 \mu \mathrm{g} / \mathrm{mL}$, respectively). $\alpha$-Terpineol was slightly active against $T$. brucei brucei blood stream forms [59]. However, these authors also reported that the discrepancy in the results might be due to different used methods and/or due to differences in stereoisomeric forms of the compounds tested.

\section{Conclusion}

The present study revealed that $S$. ceratophylla EO from Jordan was characterize by a high amount of linalool. Additionally, the EO exhibited significant antitrypanosomal activity against $T$. brucei. Moreover, the inhibitory activity of $S$. ceratophylla $\mathrm{EO}$ against $T$. brucei was stronger than that of the control ( $\alpha$-difluoromethylornithine).

This study highlights the potential of this EO as a good candidate for the treatment of the hard to cure neglected trypanosomiasis infections, also it is demonstrating that $S$. ceratophylla bears promising therapeutic potential for further drug development. Importantly, this work also clearly validated some of the traditional medicinal uses of Salvia species.

Acknowledgements This work has been conducted during the Fulbright visiting scholarship awarded to Prof. Dr. Mohammad Sanad Abu-Darwish during his Sabbatical leave from Al-Balqa' Applied University, Al-Salt, Jordan, at the National Center for Natural Products Research, School of Pharmacy, University of Mississippi, USA. The authors thank the Dean of Scientific Research, Al-Balqa Applied University, Jordan, the Binational Fulbright Commission in Jordan, Council for International Exchange of Scholars (CIES), and Institute of International Education (IIE), USA. This work was also supported by Foundation for Science and Technology (FCT), Portugal (Strategic Projects UID/NEU/04539/2013, and UID/NEU/04539/2019, UIDB/04539/2020 and UIDP/04539/2020 (CIBB)).

\section{Compliance with Ethical Standards}

Conflict of interest The authors declare that there is no conflict of interest.

Open Access This article is licensed under a Creative Commons Attribution 4.0 International License, which permits use, sharing, adaptation, distribution and reproduction in any medium or format, as long as you give appropriate credit to the original author(s) and the source, provide a link to the Creative Commons licence, and indicate if changes were made. The images or other third party material in this article are included in the article's Creative Commons licence, unless indicated otherwise in a credit line to the material. If material is not included in the article's Creative Commons licence and your intended use is not permitted by statutory regulation or exceeds the permitted use, you will need to obtain permission directly from the copyright holder. To view a copy of this licence, visit http://creativecommons.org/licenses/by/4.0/. 


\section{References}

1. H. Taifour, A. El-Oqlah, Jordan plant red list, vol. 1 (Royal Botanic Garden, Jordan, 2015)

2. S.A. Oran, Int. J. Biodiv. Cons. 6, 28-40 (2014)

3. N. Gürsoy, B. Tepe, H.A. Akpulat, Rec. Nat. Prod. 6, 278-287 (2012)

4. A. Al-Bakri, G. Othman, F. Afifi, F. Pharmacog, Mag. 6, 264-270 (2010)

5. V. Kasabri, F.U. Afifi, R. Abu-Dahab, N. Mhaidat, Y.K. Bustanji, I.M. Abaza, S. Mashallah, Rev. Roum. Chim. 59, 693-705 (2014)

6. M.B. Shehadeh, S. Sosa, G. Suaifan, R.M. Darwish, Jordan J. Pharm. Sci. 7, 153-161 (2014)

7. V. Cardile, A. Russo, C. Formisano, D. Rigano, F. Senatore, N.A. Arnold, F. Piozzi, J. Ethnopharmacol. 126, 265-272 (2009)

8. M.S. Abu-Darwish, Int. J. Phytomed. 6, 384-390 (2014)

9. J. Bero, M. Frédérich, J. Quetin-Leclercq, J. Phar. Pharmacol. 61, 1401-1433 (2009)

10. A. Tosun, S. Khan, Y.S. Kim, Á. Calín-Sánchez, X. Hysenaj, A. Carbonell-Barrachina, Trop. J. Pharm. Res. 13, 937-942 (2014)

11. T.A. Mokoka, S. Zimmermann, T. Julianti, Y. Hata, N. Moodley, M. Cal, M. Adams, M. Kaiser, R. Brun, N. Koorbanally, M. Hamburger, Planta Med. 77, 1663-1667 (2011)

12. M. Mohammadi, M. Yousefi, Z. Habibi, S. Rahmati, G. Imanzadeh, J. Ess. Oil Bear. Plants 13, 774-778 (2010)

13. E. Bağci, A. Koçak, Sci. Eng. J. Fırat. Univ. 19, 435-442 (2007)

14. K.H.C. Başer, H.G. Ağalar, F. Celep, A. Kahraman, M. Doğan, B. Demirci, B. Turk, J. Pharm. Sci. 12, 53-58 (2015)

15. H.I. Al-Jaber, Jordan J. Chem. 11, 108-119 (2016)

16. R. Abu-Dahab, F. Afifi, V. Kasabri, L. Majdalawi, R. Naffa, Pharmac. Mag. 8, 319-324 (2012)

17. M.R. Loizzo, M. Abouali, P. Salehi, A. Sonboli, M. Kanani, F. Menichini, R. Tundis, R. Nat, Prod. Res. 24, 2278-2285 (2014)

18. I. Orhan, M. Kartal, Q. Naz, A. Ejaz, G. Yilmaz, Y. Kan, B. Konuklugil, B. Sener, M.I. Choudhary, Food Chem. 103, 12471254 (2007)

19. A.T. Peana, P.S. D’Aquila, F. Panin, G. Serra, P. Pippia, M.D.L. Moretti, Phytomedicine 9, 721-726 (2002)

20. G.P.P. Kamatou, N.P. Makunga, W.P.N. Ramogola, A.M. Viljoen, J. Ethnopharmacol. 119, 664-672 (2008)

21. N.L. Montesino, M. Kaiser, R. Brun, T.J. Schmidt, Molecules 20, 14118-14138 (2015)

22. M.V.O.B. De Alencar, J.M. Castroe Sousa, H.M.L. Rolim, M.G.F. Medeiros, G.S. Cerqueira, F.R.C. Almeida, A.M.G.L. Citó, P.M.P. Ferreira, J.A.D. Lopes, A.A.C. Melo-Cavalcante, M.T. Islam, Phytother. Res. 31, 175-201 (2017)

23. M. Serakta, Z. Djerrou, H. Mansour-Djaalab, F. KahloucheRiachi, S. Hamimed, W. Trifa, A. Belkhiri, N. Edikra, Y. Hamdi Pacha, Afr. J. Tradit. Complement. Altern. Med. 10, 427-430 (2013)

24. M.S.S. Rosa, R.R. Mendonca-Filho, H.R. Bizzo, I.A. Rodrigues, R.M.A. Soares, T. Souto-Padrón, C.S. Alviano, A.H. Lopes, Antimicrob. Agents Chemother. 47, 1895-1901 (2003)

25. M. Morales, M.C. Navarro, J. Martín, A. Valero, A.M. Lara, S. Barón, F. Morillas, Rev. Ibero-Latinoamericana Paras. 68(1), 65-72 (2009)

26. A.O. Santos, T. Ueda-Nakamura, B.P. Dias, V.F. Veiga, A.C. Pinto, C.V. Nakamura, J. Ethnopharmacol. 120, 204-208 (2008)

27. E. Nibret, M. Wink, Phytomedicine 17, 911-920 (2010)

28. Council of Europe, European pharmacopoeia, 3rd edn. (Council of Europe, Strasbourg, 1997)

29. N.W. Davies, J. Chromatogr. A 503, 1-24 (1990)
30. E. Borenfreund, H. Babich, N. Martin-Alguacil, vitro Cell. Dev. Biol. 26, 1030-1034 (1990)

31. A.M. Taweel, A.M. El-Shafae, S. Perveen, G.A. Fawzy, S.I. Khan, Int. J. Pharm. 11, 372-376 (2015)

32. S.K. Jain, R. Sahu, L.A. Walker, B.L. Tekwani, J. Vis. Exp. 70, $4054(2012)$

33. S. Jain, M. Jacob, L. Walker, B. Tekwani, BMC Complement. Altern. Med. 16, 131 (2016)

34. M. Maksimovic, D. Vidic, M. Milos, M.E.S. Olic, S.A. Zic, S Siljak-Yakovlev, Biochem. Syst. Ecol. 35, 473-478 (2007)

35. M. Abu-Darwish, Z. Abu-Dieyeh, A. Al-Fraihat, S. Al-dalain, F. Afifi, J. Al-Tabbal, Int. J. Agri. Biol. 13, 981-985 (2010)

36. A.C. Figueiredo, J.G. Barroso, L.G. Pedro, J.J.C. Scheffer, Flavour. Fragr. J. 23, 213-226 (2008)

37. J.L.S. Carvalho-Filho, A.F. Blank, P.B. Alves, P.A.D. Ehlert, A.S. Melo, S.C.H. Cavalcanti, M.F. Arrigoni-Blank, R. Silva-Mann, Rev. Bras. Farmacogn. 16, 24-30 (2006)

38. R. Kumar, S. Sharma, V. Pathania, J. Ess. Oil Res. 25, 23-32 (2013)

39. M. Abdallah, R. Abu-Daha, F. Afifi, Jordan. J. Pharm. Sci. 6, 40-47 (2013)

40. H.I.J. Al-Jaber, Essent. Oil Bear. Pl. 18, 718-724 (2015)

41. S.L.D. Silva, P.M. Figueiredo, T. Yano, Acta Amazo. 37, 281-286 (2007)

42. L.C. Chiang, W. Chiang, M.Y. Chang, L.T. Ng, C.C. Lin, Am. J. Chin. Med. 31, 37-46 (2003)

43. R. Ravizza, M.B. Garibold, R. Molteni, E. Monti, Oncol. Rep. 20, 625-630 (2008)

44. J. Alzeer, B.R. Vummidi, R. Arafeh, W. Rimawi, H. Saleem, N.W. Luedtke, J. Med. Plants Res. 8, 408-415 (2014)

45. R. Zamora, Y. Vodovotz, T.R. Billiar, Mol. Med. 6, 347-373 (2000)

46. S.B. Hassan, H. Gali-Muhtasib, H. Göransson, R. Larsson, Anticancer Res. 30, 1911-1919 (2010)

47. G. Suske, Gene 238, 291-300 (1999)

48. A.R. Black, J.D. Black, J. Azizkhan-Clifford, J. Cell Phys. 188, 143-160 (2001)

49. M. Abdelrahim, I. Samudio, R. Smith, R. Burghardt, S. Safe, J. Bio. Chem. 277, 28815-28822 (2002)

50. E. Chiefari, A. Brunetti, F. Arturi, J.-M. Bidart, D. Russo, M. Schlumberger, S. Filetti, BMC Cancer 2(1), 35 (2002)

51. N.Y. Jiang, B.A. Woda, B.F. Banner, G.F. Whalen, K.A. Dresser, D. Lu, Cancer Epid. Prev. Biom. 17, 1648-1652 (2008)

52. H. Durgha, R. Thirugnanasampandan, G. Ramya, M.G. Ramanth, J. King Saud Uni.-Sci. 28, 390-395 (2015)

53. M.S. Abu-Darwish, C. Cabral, I.V. Ferreira, M.J. Gonçalves, C. Cavaleiro, M.T. Cruz, L. Salgueiro, Biomed. Res. Int. 2013, 538940 (2013)

54. R. SilveiraeSá, L.N. Andrade, D.P. Sousa, Molecules 18, 12271254 (2013)

55. J. Ma, H. Xu, J. Wu, C. Qu, F. Sun, S. Xu, Int. Immunopharmacol. 29, 708-713 (2015)

56. M. Tosun, S. Ercisli, M. Sengul, H. Ozer, T. Polat, E. Ozturk, Biol Res. 42, 175-181 (2009)

57. B. Nikmehr, H. Ghaznavi, A. Rahbar, S. Sadr, S. Mehrzadi, S. Chin, J. Nat. Med. 12, 423-427 (2014)

58. S. Ślusarczyk, S. Zimmermann, M. Kaiser, A. Matkowski, M. Hamburger, M. Adams, Planta Med. 77, 1594-1596 (2011)

59. S. Hoet, C. Stévigny, M.F. Hérent, J. Quetin-Leclercq, Planta Med. 72, 480 (2006) 